\title{
SPIRITUAL EDUCATION OF PRESCHOOL CHILDREN
}

\author{
Maryambibi Djumaniyazovna Abdullayeva
}

Lecturer, Department Of Preschool Education, Chirchik State Pedagogical Institute, Tashkent Region, Uzbekistan

\section{ABSTRACT}

This article will focus on the necessary aspects of the coverage of preschool educational organizations for children aged 2 to 6-7 years, the most important indicator of which is the characteristic of the effectiveness of preschool education. If a child goes to school without preschool education, his educational activities in primary school will not be effective enough. That is, educational adaptation - adaptation in a child proceeds poorly, his ability to enter into social relations, communication, mental activity is poorly manifested. In most cases, the child has a state of physical, psychological unavailability. The article examines the motivation for learning, the idea that a child who has not formed the first learning skills, whose mental processes are underdeveloped, lags behind in mastering.

KEYWORDS:- Spiritual education, social relations, educational skills, adoration, psychological process

\section{INTRODUCTION}

The education of a person in all respects in perfection is a long-standing dream of our people, our ancestors have been steadily looking for ways, laws and rules how to teach the younger generation enlightenment, spirituality and culture, to bring them to perfection. This was the reason for the emergence of pedagogical science. Because the achievement of enlightenment and spiritual perfection of a person is carried out under the guidance of pedagogical science.

As you know, the most important indicator characterizing the effectiveness of preschool education is the coverage of these children aged 2 to 6-7 years by preschool educational organizations.

It should be noted that $50 \%$ of the learning ability in the child's personality develops during the first four years. Another 30\% develop between the ages of four and eight. During this period, neural connections are actively developing, if neural connections are not actively formed before the child reaches the age of ten, they are not activated and "die". From this it can be seen that in the first eight years of a person's life, $80 \%$ of knowledge and the foundations of life thinking are laid.

One of the main tasks of teaching is the formation of the main components of educational activity in preschool children along with the acquisition of knowledge.

The learning task is the main component of the learning activity. Many psychologists and educators believe that the success of educational activities depends more on the ability to realize the educational task. The tasks of preschool education cover both the content of knowledge, 
CURRENT RESEARCH JOURNAL OF PEDAGOGICS 2(10): 147-151,

October 2021 DOI: https://doi.org/10.37547/pedagogics-crjp-02-10-27

ISSN 2767-3278

(C)2021 Master Journals

\section{Crossref doi) 81 Google}

Accepted $26^{\text {th }}$ October, 2021 \& Published $31^{\text {th }}$ October, 2021

skills and abilities, as well as ways of thinking and practical activity.

Educational tasks in classes with older preschool children with special needs acquire a pronounced educational and cognitive character, although in some cases their connection with practical tasks remains. The main place in this is occupied by the tasks of assimilation of knowledge. However, with the development of mental activity, consciousness of children, educational tasks for mastering practical productive and ways of mental activity begin to be fully perceived, as well as educational tasks of a creative nature. However, even at an older age, it is difficult for children to remember a learning task throughout their studies.

Children greatly admire fairy tales involving brave, conscientious heroes who overcome any difficulties with their intelligence or courage, patience or hard work, such fairy tales make children be incredibly friendly to positive heroes, intolerant of evil, injustice, jealousy, treachery.

\section{Materials}

In addition to Uzbek folk tales, many Russian folk and fraternal fairy tales are also included in the sentence of fairy tales, which children read. Uzbek writers and poets created many wonderful works for children. This is G'. Gulom, Mirmuhsin, I. Muslim, P. Believers, Sh. Se'dulla, N. Arifjonov, Q. Wisdom, Q. Muhammadiy and others.

Russian writers and poets from the list of literature dedicated to children of preschool age: B.Jitgav, S. Mikhalkov, K. The translated works of Chukovsky and others have taken a wide place. The works of foreign writers on this list are also from Sh. Also included are fairy tales of Perro, Andersen and others.
The circle of works that children read includes works of different genres: fairy tales and povests, prose and fairy tales in the form of poems, epics, poems of humor, puzzles, parables.

The educator should introduce children in each age group to a large number of works of children's art literature.Find content skills to perceive the literary work in the educator children. The child should not only listen to the work, absorb its content, but also feel the emotions and moods that the author describes.

Some elementary skills of analyzing the content of the work in preschool organizations are also found in content. In the preparatory group, children should be able to identify the main heroes of the story in the work, tell their attitude to them (who liked what), determine the genre of the work (poem, story, fairy tale).

The children's book is understandable to the child, has reached his mind and soul, that is, the child is able to understand and feel what the writer is doing in the story, only in fate he fulfills his educational role.

Educators need to know what works they are familiar with in previous age groups in order to strengthen their knowledge of the works of children. To do this, it is necessary to consider the previous Group Program at the beginning of the year and determine the material for the repetition.

When drawing up a monthly plan, the educator sets out from the recommended list of works that children will read in the next week or two. Bunda applies her functions as a composition of emotions and behavior in children, all kinds of interests and relationships around them.

Watching what children are interested in, their interaction, their games will help significantly to choose a good book.

As soon as the holiday of independence 
CURRENT RESEARCH JOURNAL OF PEDAGOGICS 2(10): 147-151,

October 2021 DOI: https://doi.org/10.37547/pedagogics-crjp-02-10-27

ISSN 2767-3278

(C)2021 Master Journals

\section{Crossref doi) gr Google}

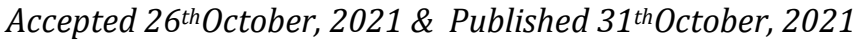

approaches, the children will see how the day is preparing for this day in the kindergarten, in the city, will remember the poem dedicated to the holiday of Navruz with great pleasure. Spring comes and thrives-when everything around blossoms, children perceive the work about spring very vividly.

The preparation of the educator begins with the determination of the purpose of using the book. The book is a means of enrichment of knowledge and dictionary about the environment, as well as a source of content of moral qualities in children, entertainment, etc. As soon as the educator determines the purpose of using the book, he will read the book before the training in order to learn the idea of the Autor, to determine the characters of the heroes of the work and their interaction. Analyzing the work in advance in this way will help the educator to convey it in an expressive way: he will master the berlsh tools (different intonations, logical accents, clear and correct ishlangan pronunciation of all words) by reading or narrating in an emotional way. If the educator has developed enough in his time and wants to give the children a familiar work to read or a story, he will again prepare for the training: he will read the work aloud several times, in order to recall the text of the work and restore the expressive means of reading, which he had previously mastered. The tutor chooses the book and, having determined the purpose of its use, draws up a training plan. On the topic of the lesson, the name of the book, the autor and how to deliver it to children - the method of reading or telling a story is indicated.

For the purpose of training, the educator sets out the educational and educational goals of the use of the book, shows how to introduce children to new words.

Show illustrations. There will certainly be an illustration in the book intended for a child of preschool age. The illustration is a picture that tells a certain part of the text, explaining some kind of moment. The illustrations in the children's book are in the same place as in tekst, because the child' himself can not read the book, and the book refers to him first with his picture. Although children love to browse through the pictures in the book, they can ignore many things in the uniig content, misunderstand, in addition, in the group there may be children whose interest in the book is not clearly felt. Children, whose attention is not stable, are also encountered: they take the book and throw away, although it turns out a palatial sheet. So it can not be believed that children are directly interested, it is necessary to educate in them suratlarni the ability to see. It is necessary to teach children to carefully look at the illustrations for a long time, to recognize in them the familiar heroes of the book, etc. It is important to teach preschool-age children to recognize the objects depicted in the picture and find similarities in them with familiar objects. This is facilitated by the following questions: What is it?, who is this?, what are they doing?, what is in his hands?, what color is it?, we have such a cap?

Children of the middle group can be asked to find out which work this picture belongs to.The illustrations are large, clearly visible from afar, they can be shown to children in class. There are books in which a picture takes up an entire page, and in the text there is only a comment to it. Reading such books is determined by the originality of the books themselves: the educator first shows the children an illustration, and then reads the corresponding text, which must be known by heart.While reading books that depict individual scenes, it is important to read the entire work from beginning to end, and then show all the illustrations. After showing the illustration, it is necessary to return to the text again, read the corresponding places of the illustration.It is recommended to conduct several 
CURRENT RESEARCH JOURNAL OF PEDAGOGICS 2(10): 147-151,

October 2021 DOI: https://doi.org/10.37547/pedagogics-crjp-02-10-27

ISSN 2767-3278

(C)2021 Master Journals

\section{Crossref doi) google}

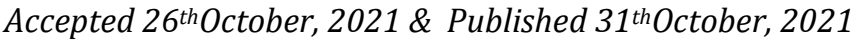

classes with older children throughout the year so that they can view illustrations of books they are familiar with. To conduct such classes, it is necessary to distribute 12-13 books of the same title to children.You should never bend the book away from the cover during the illustration demonstration. To prevent children from being distracted, a sheet of white paper should be left above the illustration on the second page.

Books of the character of giving knowledge to children of preschool age have a certain degree of difficulty. When reading them, it is possible to go to the understandingtirib by the way, showing the illustration. In order for the children to get acquainted with the illustrations of all the remaining books until the end of the lesson, they are taken to the group earlier. Bunda does not show pictures in order not to violate the integrity of children's artistic perception. After reading the book, The pictures can be switched to repeated browsing.

At the end of the training, the sight of the illustrations in the book always corresponds to the desire of the children, the main thing is to deepen the understanding heard, clarify the places where there is still uncertainty, more fully illuminate the artistic images. But it is necessary to take into account the large size of the illustrations of the bunda. If they are large enough, the children's team can easily navigate them in the training. And the illusions that are not so large, it is desirable that small groups of children were examined after training. If ignorance of certain words and phrases hinders understanding of the contents of the work in general, such words require prior explanation. This can interfere with the perception of fairy tales. For example, children achieve an understanding of the genres of folk oral creativity, in particular, the deep meaning expressed in them when reading a piece from the epics "Rustamkhon", "Alpomish" to the epic. It is possible to use illustrations in helping to master the main content of the epics.

It is very important to attract the attention of children at the beginning of the lesson. This can be achieved not by warning, swearing ("listen, then I'll ask you"), but by an interesting prelude word, a prelude conversation. Because they can use a bright picture, a riddle, the experience of children, etc. Depending on the content of the book.

When reading books with moral, aesthetic and cognitive content, careful preparation is required. Books of moral and aesthetic content help to bring up positive qualities of moral qualities and behavior in children.

Preschool educational organizations are the most basic and necessary integral part of the education system. In preschool educational organizations, the child is prepared for comprehensive schooling. The development of children's speech in this process is the most basic work.

\section{ANALYSIS AND RESULTS}

The main task of the speech development of a preschool child is the child's assimilation of the norms and rules of the native language established for each age stage, and the development of his communicative abilities.

All the achievements of the child in mastering the language system consist in fluent speech, which is considered as a meaningful, widespread thought that provides communication. It is distinguished by its meaningfulness, logic and consistency. Fluency of speech is considered an indicator of how much a child has mastered the richness of the language.

\section{Conclusion}


CURRENT RESEARCH JOURNAL OF PEDAGOGICS 2(10): 147-151,

October 2021 DOI: https://doi.org/10.37547/pedagogics-crjp-02-10-27

ISSN 2767-3278

(C)2021 Master Journals

Crossref do: 81 Google

Accepted $26^{\text {th }}$ October, 2021 \& Published $31^{\text {th }}$ October, 2021

At present, it is understood that pre-school education organizations are an integral part of the education system, which is the most basic and necessary.

In preschool organizations, the child is prepared for comprehensive school education. It is very important to prepare children for school by developing logical thinking and thinking in the process of training, their vocabulary will increase, they will speak fluently and will be able to fully express and express their thoughts. Therefore, among the classes that pass in preschool educational organizations, speech cultivation training is considered one of the most basic.

\section{REFERENCES}

1. Sh.Mirziyoyev. "We will build our great future together with our courageous and noble people." Tashkent - "Uzbekistan"2016.488 p.

2. Sh. Mirziyoyev. "Critical analysis, strict discipline and personal responsibility should be the daily rule of every leader's activity." Tashkent - "Uzbekistan" $2017.104 \mathrm{p}$.

3. The strategy of actions on the five priority areas of development of the Republic of Uzbekistan for 2017-2021. Decree of the President of the Republic of Uzbekistan No. UP-4947.

4. T. Javliyev. Traditions are a lesson of life. T., "Uzbekistan", 2012.

5. A. Aulonius. Turkish Gulistan or ethics. - T., "Teacher", 2002.

6. Djumaniyazovna, M. A. (2021). The Importance Of Innovation Clusters In The
Construction of The Third Renaissance Foundation. The American Journal of Social Science and Education Innovations, 3(06), 194-197.

7. Djumaniyazovna, M. A. (2021). ISSUES OF SPIRITUAL EDUCATION IN PRESCHOOL EDUCATION. CURRENT RESEARCH JOURNAL OF PEDAGOGICS (2767-3278), 2(06), 116-121.

8. Abdullaeva, M. D. (2020). Introduction To Social Norms That Is Implemented In The Process Of Greetings For Primary School Students. The American Journal of Social Science and Education Innovations, 2(12), 174-179.

9. Abdullaeva, M. D. (2021). Social norms related to the activities of primary school children. ACADEMICIA: AN INTERNATIONAL MULTIDISCIPLINARY RESEARCH JOURNAL, 11(2), 226-231.

10. Abdullaeva, M. D. (2021). The Teacher's Role In Developing A Sense Of Respect For Socio-Legal Norms In Primary School Children. The American Journal of Social Science and Education Innovations, 3(02), 40-45. 